\title{
Partial substitution of nitrite by chitosan and the effect on the quality properties of pork sausages
}

\author{
Substituição parcial de nitrito de sódio por quitosana e sua influência sobre a qualidade de embutidos
}

\author{
Mario GARCÍA ${ }^{1 *}$, Tatiana BELDARRAÍN ${ }^{2}$, Leonid FORNARIS ${ }^{1}$, Raúl DÍAZ ${ }^{1}$
}

\begin{abstract}
The aim of the study was to evaluate the influence of partial nitrite replacement by chitosan on the quality of Ham Visking (a type of pork sausages). Five Ham Visking formulations were elaborated modifying the sodium nitrite $(0.011 ; 0.016$ or $0.0212 \%)$ and chitosan concentrations $(0.25$ or $0.5 \%)$ in the products. Sausages were stored at $4{ }^{\circ} \mathrm{C}$ and physicochemical, microbiological, and sensorial evaluations were performed in order to estimate their shelf life. Chitosan can be used in pork sausages without affecting ensory attributes such as color although the panelists detected textural differences among the samples with chitosan, which suggests that there is some influence of deacetylation degree of chitosan on the textural behavior of sausages which still needed to be explained for a successful application of chitosan in meat products. The reduction of residual sodium nitrite did not affect the color and flavor of such products, but the use of chitosan increasedsignificantly the shelf life of sausages.
\end{abstract}

Keywords: pork sausages; chitosan; nitrite substitution; microbial quality; sensory quality; storage.

\section{Resumo}

O objetivo do estudo foi avaliar a influência da substituição parcial de nitrito de sódio por quitosana na qualidade do presunto Visking, (um tipo de embutido de carne de porco). Elaboraram-se cinco formulações do produto, modificando-se apenas as concentrações de nitrito de sódio $(0,011 \%$ e $0,016 \%)$ e quitosana $(0,25 \%$ e $0,5 \%)$. Para determinar o tempo de prateleira dos embutidos, as amostras foram armazenadas em temperaturas a $4{ }^{\circ} \mathrm{C}$, e realizaram-se análises físico-químicas, microbiológicas e sensoriais. A quitosana pode ser utilizada em embutidos suínos sem afetar atributos sensoriais como cor, apesar do fato dos provadores terem reportado diferenças na textura entre amostras com quitosana, possivelmente essas diferenças de textura sejam influenciadas pelo grau de desacetilação da quitosana. Entretanto, esses resultados ainda precisam ser esclarecidos para se poder ter uma aplicação eficiente da quitosana em embutidos. A redução do nitrito de sódio residual não afetou a cor nem o sabor destes produtos. Entretanto, quando se adicionou quitosana, foi observado um aumento no tempo de prateleira do embutido.

Palavras-chave: embutidos; quitosana; substituicao de nitrito; qualidade microbiológica; qualidade sensorial; armazenamento.

\section{Introduction}

Ham Visking is a type of pork sausage and is one of the most popular meat products in Cuba, and the demand for such a product is continuously increasing, especially by children. Ham Visking is a cured meat product. Curing contributes to the characteristic pink color, specific texture, and flavor, and provides a preservative effect especially against Clostridium botulinum (MARRIOT; LECHOWICH; PIRSON, 1981). Nitrite is the critical curing component (CASSENS, 1997).

When added to cured meats, nitrite has at least three functions (WOODS; WOOD; GIBBS, 1990), principally to inhibit the growth of food spoilage bacteria, especially Clostridium botulinum, a sporoluted microorganism that can grow under anaerobic conditions and produce a neurotoxin, which is one of the most lethal natural products known. Nitrite, together with cooking and the addition of salt, is a protection against food poisoning by this microorganism (PIERSON, 1982; ROBERTS et al., 1991). Nitrite also contributes to the flavor, probably due to the inhibition of the development of rancid off-flavors (CORNFORTH, 1996), and it reacts with myoglobin producing mononitrosylhaemochrome (KILLDAY et al., 1988), which its responsible for the characteristic pink color of cured meat.

Since the 1970s, there has been concern about a possible link between nitrite and cancer. There is no conclusive evidence that nitrite is directly carcinogenic (CANTOR, 1997), but in high doses it has been implicated as a co-carcinogen (SCHWEINSBERG; BURKLE, 1985). Some epidemiological studies have suggested a link between dietary nitrates and nitrites and the incidence of cancer (FORMAN; AL-DABBAGH; DOLL, 1985), and this is the reason why the reduction or elimination of nitrite is desirable. There are two alternatives to control the problem: i) use of agents that partially or completely replace nitrite, or ii) agents that block formation of nitrosamines

Received 29/9/2009

Accepted 14/2/2010 (004403)

${ }^{1}$ Pharmacy and Food Institute, University of Havana, Av. 23, n. 21425, CP 13600, Havana, Cuba, E-mail: marioifal@gmail.com

${ }^{2}$ Food Industry Research Institute, Carretera al Guatao, Km 3,5, CP 19200, Havana, Cuba

${ }^{*}$ Corresponding author 
in products containing conventional concentrations of nitrite (CASSENS, 1995).

Chitosan is a linear polymer of 2 -amino-2-deoxy- $\beta$-D-glucan, a deacetylated form of chitin, which is a naturally occurring cationic biopolymer (AIROLDI, 2008). It occurs as a shell component of crustaceans, as the skeletal substance of invertebrates, and as the cell wall constituent of fungi and insects. Applications of chitosan include using it as a flocculating agent, clarifying substance, thickening substance, gas-selective membrane, coating material, wound-healing factor agent, and antimicrobial agent among other uses (GARCÍA, 2008; GARCÍA et al., 2008). In addition, chitosan has recently been approved by the authorities for its use in pharmaceutical forms, and a monograph relating to chitosan hydrochloride was included in the European Pharmacopoeias (EUROPEAN..., 2005).

Chitosan exhibits in vitro antimicrobial activity against a range of foodborne microorganisms and consequently has attracted attention as a potential natural food preservative in meat products (ROLLER; COVILL, 2000; ROLLER et al., 2002; SHAHIDI; ARACHCHI; JEON, 1999).

The objective of this study was to evaluate the possibility of partial nitrite replacement by chitosan on the quality of Ham Visking pork sausages.

\section{Materials and methods}

\subsection{Sample preparation}

Refrigerated lean pork was obtained within 72 hours of slaughtering from a local meat packer, coarsely ground (MBM, Germany) and blended (RMT, Spain). Brine containing sodium chloride, trisodium phosphate, and sodium nitrite was prepared and mixed with ground pork meat (Table 1) for 30 minutes. The mixture was left to rest for 24 hours and was mixed again for 30 minutes. Chitosan oligomers of low (Pharmacy and Food Institute, University of Havana, Cuba) and medium (Biomaterials Center, University of Havana, Cuba) deacetylation

Table 1. Formulation of Visking-type pork sausage with different levels of sodium nitrate and chitosan.

\begin{tabular}{lccccc}
\hline \multirow{2}{*}{ Ingredients (\%) } & \multicolumn{5}{c}{ Treatments } \\
\cline { 2 - 6 } & 1 & 2 & 3 & \multicolumn{1}{c}{4} & \multicolumn{1}{c}{5} \\
\hline Pork & 87.0 & 87.0 & 87.0 & 87.0 & 87.0 \\
Sodium chloride & 2.67 & 2.68 & 2.67 & 2.68 & 2.73 \\
Sodium nitrite & 0.016 & 0.011 & 0.016 & 0.011 & 0.0212 \\
$\begin{array}{l}\text { Trisodium } \\
\text { phosphate }\end{array}$ & 0.3 & 0.3 & 0.3 & 0.3 & 0.3 \\
Chitosan & $0.25 \mathrm{a}$ & $0.5 \mathrm{a}$ & $0.25 \mathrm{~b}$ & $0.5 \mathrm{~b}$ & 0.0 \\
$\quad$ & 9.77 & 9.6 & 9.77 & 9.6 & 9.95 \\
\hline Water & & & & &
\end{tabular}

Table 2. Characteristics of the chitosan oligomers used.

\begin{tabular}{lcc}
\hline \multirow{2}{*}{ Parameters } & \multicolumn{2}{c}{ Chitosan } \\
\cline { 2 - 3 } & I & II \\
\hline Molecular weight & $1,6 \times 10^{3}$ & $6,2 \times 10^{3}$ \\
Deacetylation degree (\%) & 83,02 & 70 \\
\hline
\end{tabular}

degrees (Table 2), previously dissolved in lactic acid at $1 \%$ $(\mathrm{v} / \mathrm{v})$, were added to the treated products and mixed until fully homogeneous. The sausages were stuffed (MAINCA, Mod. 3763, Spain) into a permeable fibrous casing (60 $\mathrm{mm}$ of diameter, NaloBar, Spain), dried $\left(50^{\circ} \mathrm{C}\right.$ for 20 minutes $)$, smoked $\left(60^{\circ} \mathrm{C}\right.$ for 30 minutes), and cooked to an internal temperature of $70-71^{\circ} \mathrm{C}$ using a smokehouse. The cooked sausage was water-spray cooled for 5 minutes and dried at room temperature for 30 minutes. All samples were stored between 2 and $4^{\circ} \mathrm{C}$ until analysis.

Five Visking-type pork sausage treatments were formulated (Table 1) modifying only the concentrations of sodium nitrite and chitosan. The maximum nitrite level used was that allowed by sanitary authorities of Cuba (NRIAL 79-13) (NORMA..., 1984).

\subsection{Product characterization}

\section{Physicochemical analyses}

Proximate analysis was determined in the samples after the drying process (day 0) and during storage. The moisture content (NC-ISO 1442) (NORMA..., 2002a), protein (NC-ISO 937) (NORMA..., 2006), fat (NC-ISO 1443) (NORMA..., 2004b), sodium chloride (NC-ISO 1443) (NORMA..., 2004c), sodium nitrite (NC-ISO 1443) (NORMA..., 2004a), and water activity were estimated according to the method of Krispien, Rõdel and Lestner (1979).

The $\mathrm{pH}$ measurements were performed in a $\mathrm{pH}$ meter (Metrohm Herisau, Mod. E-510) after homogenizing a $10 \mathrm{~g}$ portion of sausage in $90 \mathrm{~mL}$ of distilled water for 1 minute, according to NC-ISO 2917 (NORMA... 2004d).

\section{Sensory evaluation}

The methodology according to ISO 4121 (1987), with some modifications, was used to evaluate the initial sensory qualities of the sausages. A panel of fifteen semi-trained judges was used to evaluate products on a 7-point scale: 1 , very poor and 7 , excellent. Sausages were sliced into $2 \mathrm{~cm}$ thick pieces and served to each panelist separately under white illumination. Water was provided for cleansing the palate between samples. The sensory parameters used in the present study were appearance, color, flavor, and texture, and were evaluated independently by the panelists four different times. Each panelist expressed his/her preference by completing a questionnaire.

\subsection{Microbiological evaluation}

A $10 \mathrm{~g}$ sample and $90 \mathrm{~mL}$ of sterilized distilled water were homogenized. The homogenate was serially diluted with sterilized distilled water, and the dilutions were spread on the specific medium in aerobic conditions. Total aerobic bacteria (35 $\pm 1{ }^{\circ} \mathrm{C}, 48$ hours), (NC-ISO 4833) (NORMA..., 2003), and coliform bacteria counts $\left(37 \pm 1^{\circ} \mathrm{C}, 18\right.$-24 hours), (NC-ISO 4832) (NORMA..., 2002b), were performed with plate count agar (PCA, Biocen, Havana, Cuba). The violet red bile glucose agar (VRBGA, Biocen) and malt extract agar (MEA, Biocen) were used to grow Enterobacteriaceae $\left(37^{\circ} \mathrm{C}, 18-24\right.$ hours), (NC 76-04-04) (NORMA..., 1982), fungi and yeasts $\left(30^{\circ} \mathrm{C}, 48-72\right.$ hours), 
(NC-ISO 7954) (NORMA..., 2002c), respectively. Colony forming units (CFU) per gram in plates were counted, at a dilution giving 30-300 CFU per plate, with Micro Counter.

\subsection{Estimation of shelf life}

The product samples were hung in bars and stored between 2 and $4{ }^{\circ} \mathrm{C}$. Sensory evaluation and microbiological behavior were used as rejection criteria for shelf life determination. 15 semi-trained panelists qualified the samples as acceptable or not during the study, based on the appearance, color, odor, flavor, and texture of the stored product, as well as any change in its initial quality. When qualifying a sample as unacceptable, the judge was asked to describe the reason for such judgment in order to know in which way the samples were losing its initial quality. A partial stepped design was used, in which the number of experimental units were equal in each sampling period until the first rejection appeared. From that moment on, the time between successive evaluations diminishes (CANTILLO; FERNÁNDEZ; NÚNEZ DE VILLAVICENCIO, 1994).

\subsection{Statistical analysis}

All experiments were performed in triplicate. Analyses of Variance were performed using STATISTICS software (STATSOFT, 1998), and the Duncan's multiple range tests were used to compare differences among mean values. Mean values were reported, and the significance was defined at $\mathrm{p} \leq 0.05$.

In the estimation of shelf life, the coincidence in the verdict of sensorial evaluation with the minimum significant number of judges was taken as failure criterion considering a binomial distribution $(\mathrm{p}=0.01)$. The results obtained were processed as incomplete failure data using the Risks Plotting software method (CANTILLO; FERNÁNDEZ; NÚNEZ DE
VILLAVICENCIO, 1994) from which 5\% deteriorated units were selected (ANDÚJAR, 1987).

\section{Results and discussion}

\subsection{Characterization of Visking-type pork sausages}

Table 3 shows the results of the physicochemical evaluations of the products at time zero. The moisture values of all treatments were about 64 to $70 \%$, in accordance with those found by García et al. (2008) for this kind of product. On the other hand, the percentage values of proteins, sodium chloride, and $\mathrm{pH}$ are also in the range permitted for these products and is in agreement with those reported by other authors for cured products (GUERRA, 2003). Furthermore, the $\mathrm{pH}$ values of these products were between 5.8 and 6 , which enabled to development of the functional properties of proteins in the meat (BELDARRAÍN, 2006).

All values of sodium nitrite concentration were less than $125 \mathrm{ppm}$, and the treatments that received the smallest amount of sodium nitrite were those that presented less residual nitrite. The sodium nitrite concentration in the control treatment was $110.97 \mathrm{ppm}$, which means that the residual nitrite was $52.2 \%$ of the initially added amount, whereas for the rest of treatments, this percentage value was smaller. The addition of chitosan of different degrees of deacetylation did not affect the bromatological properties of pork sausages.

Table 4 shows the results of the microbiological analyses of the sausages. It can be observed that the values of microbial counts are in accordance with those allowed in Cuba for pork sausages (NC 585) (NORMA..., 2008).

Table 3. Characteristics of prepared Visking-type pork sausages with different levels of sodium nitrate and chitosan $(n=3)$.

\begin{tabular}{|c|c|c|c|c|c|}
\hline \multirow[t]{2}{*}{ Treatments } & \multicolumn{5}{|c|}{ Parameters } \\
\hline & Moisture (\%) & $\begin{array}{c}\text { Proteins } \\
(\%)\end{array}$ & $\begin{array}{c}\text { Sodium chloride } \\
(\%)\end{array}$ & $\begin{array}{l}\text { Sodium nitrite } \\
(\mathrm{ppm})\end{array}$ & $\mathrm{pH}$ \\
\hline 1 & 64.54 & 14.8 & 2.40 & $86(3) b$ & 6.00 \\
\hline 2 & 68.83 & 14.7 & 2.49 & $57(2) a$ & 6.00 \\
\hline 3 & 67.52 & 14.9 & 2.45 & $86(3) b$ & 5.90 \\
\hline 4 & 69.69 & 14.7 & 2.43 & $57(2) a$ & 5.95 \\
\hline 5 & 69.97 & 14.8 & 2.57 & $111(6) c$ & 5.87 \\
\hline
\end{tabular}

Mean (Standard deviation); Different letters (a-c) differ significantly ( $\mathrm{p} \leq 0.05)$.

Table 4. Changes in microbial population $\left(\log C F U \cdot g^{-1}\right)$ of prepared Visking-type pork sausages $(n=2)$.

\begin{tabular}{|c|c|c|c|c|c|c|}
\hline Treatments & $\begin{array}{c}\text { Storage } \\
\text { period }(\mathrm{d})\end{array}$ & $\begin{array}{c}\text { Total aerobic } \\
\text { bacteria }\end{array}$ & $\begin{array}{c}\text { Coliform } \\
\text { bacteria }\end{array}$ & Entero-bacteriaceae & Fungi & Yeast \\
\hline \multirow[t]{2}{*}{1} & 0 & 2.75 & 1.0 & 1,0 & 1.0 & 1.0 \\
\hline & 35 & $>7$ & 2.8 & 2.53 & 1.0 & 4.0 \\
\hline \multirow[t]{2}{*}{2} & 0 & 1.0 & 1.0 & 1.0 & 1.0 & 1.0 \\
\hline & 35 & $>7$ & 3.0 & 2.87 & 1.0 & 4.0 \\
\hline \multirow[t]{2}{*}{3} & 0 & 1.5 & 1.0 & 1.0 & 1.0 & 1.0 \\
\hline & 35 & $>7$ & 2.69 & 3.0 & 1.0 & 4.0 \\
\hline \multirow[t]{2}{*}{4} & 0 & 1.0 & 1.0 & 1.0 & 1.0 & 1.0 \\
\hline & 35 & $>7$ & 2.91 & 2.87 & 1.0 & 4.0 \\
\hline \multirow[t]{2}{*}{5} & 0 & 2.48 & 1.0 & 1.0 & 1.0 & 1.0 \\
\hline & 21 & $>7$ & 3.0 & 3.0 & 1.0 & 4.0 \\
\hline
\end{tabular}


Table 5 shows the sensory scores for the sausages. Statistical significance was not found ( $\mathrm{p} \leq 0.05$ ) among all sensory parameters measured of sausages treated with chitosan and the control samples, which means that chitosan can be use in the elaboration of this kind of cured products without affecting its sensorial quality. The panelists commented on some textural differences among the samples and reported a qualitative higher cohesiveness and elasticity in treatments 3 and 4 than in the others. However, at the same time, they reported on a less marked cured flavor; the different deacetylation degrees of chitosans are the probable cause of these effects. Youn et al. (1999) reported that the hardness of the sausage increased with an increase in the molecular weight of chitosan, and, especially, viscosity increased at the highest molecular weight $(120,000 \mathrm{kDa})$, which may cause adverse effect on processing.

According to the panelists, the treatments' order of preference was treatments 1 and 2, followed by treatments 3 and 4, and lastly the control treatment due to the higher amount of salt added in this treatment in spite of being the traditional formulation for this product, which is a disadvantage since the panelists preferred less salted products. The addition of chitosan oligomer in the emulsion-type pork sausage product did not change its overall acceptance in accordance with the findings by with Jo et al. (2001).

\subsection{Estimation of shelf life of Ham Visking pork sausages}

The $\mathrm{pH}$ changes in fresh Ham Visking pork sausages during storage at $2-4{ }^{\circ} \mathrm{C}$ are shown in Figure 1. On the day of

Table 5. Sensory evaluation scores of prepared Visking-type pork sausage with different levels of sodium nitrate and chitosan $(n=15)$.

\begin{tabular}{ccccc}
\hline \multirow{2}{*}{ Treatments } & \multicolumn{4}{c}{ Attributes } \\
\cline { 2 - 5 } & Appearance & Color & Flavor & Texture \\
\hline 1 & $6.2(0.3)$ & $6.2(0.4)$ & $6.2(0.6)$ & $6.1(0.5)$ \\
2 & $5.9(0.3)$ & $5.8(0.5)$ & $5.8(0.7)$ & $6.0(0.6)$ \\
3 & $6.1(0.5)$ & $5.8(0.7)$ & $5.8(0.8)$ & $6.2(0.6)$ \\
4 & $6.1(0.3)$ & $5.9(0.5)$ & $5.8(0.6)$ & $6.2(0.6)$ \\
5 & $5.8(0.4)$ & $5.7(0.5)$ & $5.8(0.7)$ & $6.0(0.4)$ \\
\hline
\end{tabular}

Mean (Standard deviation).

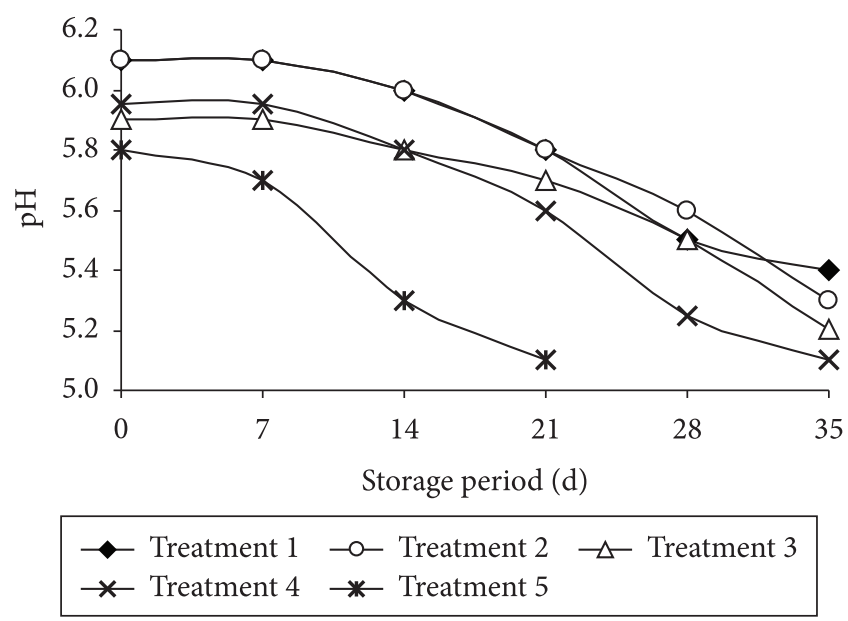

Figure 1. Changes in $\mathrm{pH}$ values during storage period $(\mathrm{n}=3)$. preparation, the $\mathrm{pH}$ of all batches ranged between 5.8 and 6.15 . These values were similar to those reported in previous studies (CLAUS; HUNT, 1991; JO et al., 2001; SANTOS et al., 2003; GARCÍA et al., 2008) for pork sausages. It can be observed that in treatments with chitosan there is a tendency for constant $\mathrm{pH}$ values until $7^{\text {th }}$ day of storage, which can be due to the antimicrobial effects described for chitosan on spoilage microorganisms. From that moment on, it starts a gradual decrease in $\mathrm{pH}$ values although less significant in samples with chitosan.

During storage, the microbial counts increased in all samples, and at the end of the study, the total counts of aerobic microorganism exceeded the acceptable maximum levels $\left(10^{7} \mathrm{CFU}^{-1}\right.$ ) (INSTITUTE OF FOOD SCIENCE AND TECHNOLOGY, 1999) evidencing the decomposition signs in this product. The Enterobacteriaceae and coliforms counts increased until $3 \log$ CFU.g ${ }^{-1}$; these counts were below the acceptable maximum levels for these microorganisms.

The samples rejected presented yeasts counts of $4 \log$ UFC.g-1 and fungi and fecal coliform counts of $1 \log$ UFC. ${ }^{-1}$ without the presence of Staphylococcus aureus.

In general, the products fulfilled the sanitary regulation requirements, and no significant changes were noticed during storage. Several authors (SAGOO; BOARD; ROLLER, 2002) have informed that the use of chitosan in meat and meat products inhibit the development of the spoilage bacteria, but there are discrepancies about their effectiveness against the acid-lactic bacteria.

In contrast, Darmadji and Izumimoto (1994) reported that Staphylococci, coliforms, Gram-negative bacteria, Micrococci, and Pseudomonas in meat during storage at $30^{\circ} \mathrm{C}$ for 48 hours and $4{ }^{\circ} \mathrm{C}$ for 10 days were inhibited by the presence of chitosan. Sagoo, Board and Roller (2002) and Georgantelis et al. (2007) found that the treatment with chitosan under the concentration of $0.3-0.6 \%$ and $1 \%$, respectively, increased the shelf-life of fresh pork sausages stored at chill temperatures from 7 to 15 days.

After the $21^{\text {rst }}$ day, the judges rejected the product without the addition of chitosan due to its appearance, formation of a superficial slime, and its acid taste, according with the decrease of $\mathrm{pH}$ values (Figure 1), which could due to the growth of the lactic acid bacteria indicated by the increase of total aerobic bacteria counts. Tables 6 and 7 show the outputted results from the software for the estimation of shelf life of food products for the control treatments and the treatments with chitosan, respectively. It can be observed that Kolmogorov-Smirnov test indicates that the probabilistic distribution of failure times can be described by Weibull distribution. According to the Risks Plotting, shelf life for Ham Visking without chitosan lies between 15 and 25 days, whereas for Ham Visking with chitosan, it lies between 33 and 37 days ( $p \leq 0.05$ ), and that is a consequence of the chitosan antimicrobial activity showed by the microbiological results. 
Table 6. Output of Risks Plotting software for Visking-type pork sausages without chitosan.

\begin{tabular}{|c|c|c|c|}
\hline Programa & PR-1.01 & -IIIA- & Minal \\
\hline \multicolumn{4}{|l|}{$\begin{array}{l}\text { Fichero de datos: trabajo.dat } \\
\text { Durabilidad de Jamón Visking }\end{array}$} \\
\hline \multicolumn{4}{|c|}{ Parametros de la distribucion de Weibull } \\
\hline Parámetro & Valor & Límite inferior & Límite superior \\
\hline De escala $(\alpha)$ & 23.3217 & 20.1273 & 27.0231 \\
\hline De Forma $(\beta)$ & 15.8900 & 7.6693 & -221.0579 \\
\hline \multicolumn{4}{|c|}{ Medidas de tendencia central y de dispersion } \\
\hline Valor esperado & {$[E(t)]$} & $=$ & 22.5602 días \\
\hline Desviación típica & {$[\operatorname{Var}(\mathrm{t})]^{\wedge} 1 / 2$} & $=$ & 0.6061 días \\
\hline \multicolumn{4}{|l|}{ Percentiles } \\
\hline Percentil (\%) & Valor & Límite inferior & Límite superior \\
\hline 01 & 17.459102 & 11.6958 & 26.06361 \\
\hline 05 & 19.34555 & 14.9996 & 24.9507 \\
\hline 10 & 20.24208 & 16.69778 & 24.53869 \\
\hline 20 & 21.220907 & 18.57612 & 24.24239 \\
\hline 30 & 21.85667 & 19.72049 & 24.22424 \\
\hline 50 & 22.78995 & 20.96491 & 24.77387 \\
\hline 70 & 23.59577 & 21.37503 & 26.04723 \\
\hline 90 & 24.57853 & 21.3533 & 28.29091 \\
\hline 95 & 24.98897 & 21.27264 & 29.35455 \\
\hline 99 & 25.67442 & 21.09858 & 31.24266 \\
\hline \multicolumn{4}{|c|}{ Prueba de bondad de ajuste de Kolmogorov-Smirnov } \\
\hline No. observaciones & $\mathrm{D} \max$ & K-S-D (0.05) & \\
\hline 5 & 0.266 & 0.5650 & \\
\hline
\end{tabular}

La distribución de probabilidades de los tiempos de fallos para un nivel de significación $\alpha=0.05$ puede ser descrita por la ley de Weibull.

Table 7. Output of Risks Plotting software for Visking-type pork sausages with chitosan.

\begin{tabular}{|c|c|c|c|}
\hline Programa & PR-1.01 & -IIIA- & Minal \\
\hline \multicolumn{4}{|c|}{$\begin{array}{l}\text { Fichero de datos: trabajo.dat } \\
\text { Durabilidad de las variantes de Jamón Visking con quitosana }\end{array}$} \\
\hline \multicolumn{4}{|c|}{ Parametros de la distribucion de Weibull } \\
\hline Parámetro & Valor & Límite inferior & Límite superior \\
\hline $\begin{array}{l}\text { De escala }(\alpha) \\
\text { De Forma }(\beta)\end{array}$ & $\begin{array}{l}35.0224 \\
22.6429\end{array}$ & $\begin{array}{l}34.5072 \\
85.5671\end{array}$ & $\begin{array}{r}35.5453 \\
-85.5671\end{array}$ \\
\hline \multicolumn{4}{|c|}{ Medidas de tendencia central y de dispersion } \\
\hline Valor esperado & {$[\mathrm{E}(\mathrm{t})]$} & $=$ & 35.0224 días \\
\hline Desviación típica & {$[\operatorname{Var}(\mathrm{t})] \wedge 1 / 2$} & $=$ & 0.0000 días \\
\hline \multicolumn{4}{|l|}{ Percentiles } \\
\hline Percentil (\%) & Valor & Límite inferior & Límite superior \\
\hline 01 & 35.02243 & 32.28549 & 37.99138 \\
\hline 05 & 35.02243 & 33.24715 & 36.8925 \\
\hline 10 & 35.02243 & 33.67141 & 36.42766 \\
\hline 20 & 35.02243 & 34.1002 & 35.96961 \\
\hline 30 & 35.02243 & 34.34379 & 35.71448 \\
\hline 50 & 35.02243 & 34.56807 & 35.48276 \\
\hline 70 & 35.02243 & 34.50606 & 35.54653 \\
\hline 90 & 35.02243 & 34.21643 & 35.84741 \\
\hline 95 & 35.02243 & 34.07416 & 35.99709 \\
\hline 99 & 35.02243 & 33.83028 & 36.25659 \\
\hline \multicolumn{4}{|c|}{ Prueba de bondad de ajuste de Kolmogorov-Smirnov } \\
\hline No. observaciones & $\mathrm{D} \max$ & K-S-D (0.05) & \\
\hline 5 & 0.266 & 0.5448 & \\
\hline
\end{tabular}

La distribución de probabilidades de los tiempos de fallos para un nivel de significación $\alpha=0.05$ puede ser descrita por la ley de Weibull. 


\section{Conclusions}

This study showed that chitosan can be used in pork sausages without affecting sensory attributes such as color although the panelists detected textural differences among the samples with chitosan, which suggests that there is some influence of the deacetylation degree of chitosan on the textural behavior of sausages which still needed to be further investigated for a successful application of chitosan in meat products. The reduction of residual sodium nitrite did not affect the color and flavor of the products studied, but a significant increase in shelf life was obtained when chitosan was added.

\section{Acknowledgements}

The authors thank the Food Industry Research Institute of Ministry of Food Industry of Cuba.

\section{References}

AIROLDI, C. A relevante potencialidade dos centros básicos nitrogenados disponíveis em polímeros inorgânicos e biopolímeros na remoção catiônica. Quimica Nova, v. 31, n. 1, p. 144-153, 2008. http://dx.doi.org/10.1590/S0100-40422008000100026

ANDÚJAR, G.; HERRERA, H. The distribution of failure data for meat products. In: INTERNATIONAL CONGRESS OF FOOD SCIENCE AND TECHNOLOGY, 33., Helsinki. Proceedings... Helsinki, 1987. v. 2 p. 396-398.

BELDARRAÍN, T. Desarrollo de un rollo de carne de res reestructurada económico y duradero. 2006. 115 f. Thesis (Food Science and Technology Master)-Instituto de Farmacia y Alimentos, Universidad de La Habana, la Habana, 2006.

CANTILLO, J.; FERNÁNDEZ, C. M.; NÚNEZ DE VILLAVICENCIO, M. Durabilidad de alimentos: Métodos de estimación. La Habana, Cuba: Instituto de Investigaciones para la Industria Alimenticia, 1994.

CANTILLO, J.; FERNÁNDEZ, C. M.; NÚNEZ DE VILLAVICENCIO, M. Software para la estimación probabilística de la vida de anaquel de los alimentos. In: MULET, A.; ORDORICA, C.; BON, J. (Eds.). II Taller de Herramientas de Cálculo en Ingeniería de Alimentos. Valencia: Universidad Politécnica de Valencia. Disponível em: $<$ http://www.upv.es/dtalim/herraweb.htm \#IITaller>.

CANTOR, K. P. Drinking water and cancer. Cancer Causes Control, v. 8, p. 292-308, 1997. PMid:9498894. http://dx.doi.org/10.1023/A:1018444902486

CASSENS, R. G. Use of sodium nitrite in cured meat today. Food Technology, v. 7, p. 72-115, 1995.

CASSENS, R. G. Residual nitrite in cured meat. Food Technology, v. 9, p. 53-55, 1997.

CLAUS, J.; HUNT, M. Low fat, high added-water bologna formulated with textura-modifying ingredients. Journal of Food Science, v. 56, p. 643-647, 1991. http://dx.doi.org/10.1111/j.1365-2621.1991. tb05347.x

CORNFORTH, D. P. Role of nitric oxide in treatment of foods. In: LANCASTER, J. R. (Ed.) Nitric Oxide: Principles and Actions. San Diego: Academic Press, 1996. p. 259-287.

DARMADJI, P.; IZUMIMOTO, M. Effect of chitosan in meat preservation. Meat Science, v. 38, n. 2, p. 243-254, 1994. http://dx.doi.org/10.1016/0309-1740(94)90114-7
EUROPEAN DIRECTORATE FOR THE QUALITY OF MEDICINES - EDQM. European Pharmacopoeia. 3th ed. Strasbourg, France: Council of Europe, 2005.

FORMAN, D. A.; AL-DABBAGH, S.; DOLL, R. Nitrates, nitrites and gastric cancer in Great Britain. Nature, n. 313, p. 620-625, 1985. PMid:3974695. http://dx.doi.org/10.1038/313620a0

GARCÍA, M. Películas y cubiertas de quitosana en la conservación de vegetales. Ciencia y Tecnología de los Alimentos, v. 18, n. 1, p. 71-76, 2008.

GARCÍA, M. et al. Envasado activo de embutidos. Ciencia y Tecnología de los Alimentos, v. 18, n. 2, p. 1-7, 2008.

GEORGANTELIS, D. et al. Effect of rosemary extract, chitosan and a-tocopherol on microbiological parameters and lipid oxidation of fresh pork sausages stored at $4{ }^{\circ} \mathrm{C}$. Meat Science, v. 76, p. 172-181, 2007. http://dx.doi.org/10.1016/j.meatsci.2006.10.026

GUERRA, M. A. Tecnología de elaboración de productos curados de alto rendimiento. La Habana: Report, Instituto de Investigaciones para la Industria Alimenticia, 2003. $53 \mathrm{p}$.

INSTITUTE OF FOOD SCIENCE AND TECHNOLOGY. Development and use of microbiological criteria for foods. London: IFST, 1999.

INTERNATIONAL ORGANIZATION FOR STANDARD IZATION ISO. ISO 4121: Sensory Analysis. Methodology. Evaluation of food products by methods using scales. Genève: ISO, 1987.

JO, C. et al. Quality properties of pork sausage prepared with watersoluble chitosan oligomer. Meat Science, v. 59, n. 4, p. 369-375, 2001. http://dx.doi.org/10.1016/S0309-1740(01)00089-4

KILLDAY, B. K. et al. Structural characterization of nitrosylhemochromogen of cooked cured meat: implications in the meat-curing reaction. Journal of Agricultural and Food Chemestry, v. 36, p. 909-914, 1988. http://dx.doi.org/10.1021/ jf00083a006

KRISPIEN, K.; RÖDEL, W.; LEISTNER, L. Vorschlag zur Berechnung der Wasseraktivitaet (aw-Wert) von Fleischerzeugnissen aus den Gehalten von Wasser und Kochsalz. Fleischwirtschaft, v. 59, n. 8, p. 1173-1177, 1979.

MARRIOT, N. G.; LECHOWICH, R. V.; PIRSON, M. D. Use of nitrite and nitrite-sparing agents in meats: a review. Journal of Food Protection, v. 44, n. 11, p. 881-885, 1981.

NORMA CUBANA - NC. NC 76-04-04:Determinación de Enterobacterias. Cuba: Oficina Nacional de Normalización, 1982.

NORMA CUBANA - NC. NC- ISO 1442: Carne y productos cárnicos. Determinación del contenido de humedad: método de referencia. Cuba: Oficina Nacional de Normalización, 2002a.

NORMA CUBANA - NC. NC-ISO 4832: Microbiología de alimentos para consumo humano y animal. Guía general para la enumeración de coliformes. Técnica de placa vertida. Cuba: Oficina Nacional de Normalización, 2002b.

NORMA CUBANA - NC. NC-ISO 7954: Microbiología de alimentos de consumo humano y animal. Guía general para la enumeración de levaduras y mohos. Técnica de placa vertida a $25^{\circ} \mathrm{C}$. Cuba: Oficina Nacional de Normalización, 2002c.

NORMA CUBANA - NC. NC-ISO 4833: Microbiología de alimentos de consumo humano y animal. Guía general para la enumeración de microorganismos. Técnica de placa vertida. Cuba: Oficina Nacional de Normalización, 2003.

NORMA CUBANA - NC. NC- ISO: 357: Carne y productos cárnicos. Determinación del contenido de nitrito. Cuba: Oficina Nacional de Normalización, 2004a. 
NORMA CUBANA - NC. NC-ISO 1443: Carne y productos cárnicos. Métodos de ensayos. Determinación de grasa butirométrica. Cuba: Oficina Nacional de Normalización, 2004b.

NORMA CUBANA - NC. NC-ISO 1841-1: Carne y productos cárnicos. Determinación del contenido de cloruro. Parte 1: Método de Volhard. Cuba: Oficina Nacional de Normalización, 2004c.

NORMA CUBANA - NC. NC-ISO 2917: Carne y productos cárnicos. Medición del pH. Método de referencia. Cuba: Oficina Nacional de Normalización, 2004d.

NORMA CUBANA - NC. NC-ISO 937: Carne y productos cárnicos. Determinación del contenido de proteínas. Cuba: Oficina Nacional de Normalización, 2006.

NORMA CUBANA - NC. NC 585: Contaminantes microbiológicos en alimentos. Requisitos sanitarios. Cuba: Oficina Nacional de Normalización, 2008.

NORMA RAMAL DE LA INDUSTRIA ALIMENTARIA - NRIAL. NRIAL 79-13: Proceso productivo de jamón Visking. Cuba, 1984.

PIERSON, M. D. Nitrite, nitrite alternatives and the control of Clostridium botulinum in cured meats. Critical Reviews in Food Science and Nutrition, v. 17, p. 141-187, 1982. PMid:6751698. http://dx.doi.org/10.1080/10408398209527346

ROBERTS, T. A. et al. Nitrite. In: RUSSELL, N. J.; GOULD, G. W. (Eds.). Food Preservatives. Glasgow: Blackie Academic, 1991. p. 89-110.

ROLLER, S.; COVILL, N. The antimicrobial properties of chitosan in mayonnaise and mayonnaise-based shrimp salads. Journal of Food Protection, v. 63, n. 2, p. 202-209, 2000.
ROLLER, S. et al. Novel combinations of chitosan, carnocin and sulphite for the preservation of chilled pork sausages. Meat Science, v. 62 , n. 2, p. 165-177, 2002. http://dx.doi.org/10.1016/S03091740(01)00243-1

SAGOO, S.; BOARD, R.; ROLLER, S. Chitosan inhibits growth of spoilage microorganisms in chilled pork products. Food Microbiology, v. 19, n. 2/3, p. 175-182, 2002. http://dx.doi. org/10.1006/fmic.2001.0474

SANTOS, R. et al. Durabilidad de salchichas empacadas al vacío. Alimentaria: Revista de Tecnología e Higiene de los Alimentos, n. 340, p. 41-44, 2003.

SCHWEINSBERG, F.; BURKLE, V. Nitrite: a co-carcinogen? Jounal of Cancer Research and Clinical Oncology, n. 109, p. 200-202, 1985.

SHAHIDI, F.; ARACHCHI, J. K. V.; JEON, Y. J. Food applications of chitin and chitosans. Trends in Food Science and Technology, v. 10, p. 37-51, 1999. PMid:21299575. http://dx.doi.org/10.1016/ S0924-2244(99)00017-5

STATSOFT. Statistics for Windows release 5.1. Tulsa, USA: StatSoft, Inc., 1998.

WOODS, L. F. J.; WOOD, J. M.; GIBBS, P. A. Nitrite. In: GOULD, G. W. (Ed.) Mechanisms of Action of Food Preservation Procedures. London: Elsevier Applied Science, 1990. p. 225-246.

YOUN, S. et al. Effect on storage property and quality in meat sausage by added chitosan. Journal of Chitin and Chitosan, v. 4, n. 4, p. 189-195, 1999. 